\title{
INVESTIGATING CONTAGION AND MARKET INTERDEPENDENCE DURING THE GLOBAL FINANCIAL CRISIS
}

\author{
lorgulescu, F.
}

\begin{abstract}
This paper examines the roles played by market interdependence and contagion in the propagation of the 2007-2009 global financial crisis. For this purpose, five aggregate indices were employed, representing all the major financial markets from each geographical region. The data series are daily and they cover the period between 2002 and 2014. The presence of contagion and market interdependence was assessed by means of the values and value changes of the correlation coefficients between the ante crisis (2002-2007), the crisis (2007-2009) and the post crisis (20092014) intervals, as well as with the aid of a spillover index. The results indicate a high degree of interdependence between the global financial markets even before the occurrence of the crisis. On the other hand, there is evidence that the crisis spread through contagion mainly from the developed financial markets of Europe and North America to the emerging centers in Africa and Latin America while the markets from the Asia/Pacific region displayed lower correlations which may have given opportunities for the mitigation of losses. Moreover, since the majority of the correlation coefficients have not decreased significantly after the 2007-2009 period, it seems that the crisis intensified the degree of global financial integration. ${ }^{1}$
\end{abstract}

Keywords: contagion; interdependence; crisis; correlation; spillover

JEL classification: G01, G15

\section{Introduction}

Disruptions, shocks and, ultimately, crises appear to be regular occurrences in the global financial environment. Moreover, a long history of financial distress episodes points out that market crashes have a clear tendency to spread from one market to another, sometimes reaching even remote financial centers. The recent global crisis originated in the US but spread swiftly to every corner of the world exhibiting a clear example of the threats posed by the transmission of financial instability between markets. Consequently, due to the high degree of financial integration nowadays, even what may seem a local crisis has the potential to become a force to be reckoned with.

The mechanics of crises' transmission have captured the attention of many researchers which, beginning with the 1990s, led to the fast development of literature on this topic. Most works have revolved around two main factors that allow for and enhance the transmission of crises: interdependence and contagion. Forbes and Rigobon (2002) defined contagion as a significant increase in market comovement after the occurrence of a shock in one country. On the other hand, interdependence describes a high level of market comovement irrespective of the considered period.

Interdependence and contagion have been studied extensively in the context of the October 1987 crash, the Mexican peso devaluation (1994), the Asian crisis (1997), the

1 An earlier version of this paper has been presented at the 15th International Joint Conference: Central and Eastern Europe in the Changing Business Environment, in Prague, May 29, 2015. 
following Russian (1998) and Brazilian (1999) crises and culminated with efforts to understand the sequence of events which started as a subprime crisis in the US and turned into a serious global recession. Following in the footsteps of previous research, this paper sets out to study the relationships between the main financial markets in the world in order to find evidence underlying the rapid propagation of financial turmoil during the 2007-2009 markets fall. Both interdependence and contagion are taken into account and investigated as plausible factors for the spread of the crisis.

Taking into account the aforementioned objective, the paper is structured as follows: Section 2 gives an overview of the previous research concerning the roles played by market interdependence and contagion in the development of past crises, as well as the main methods for investigating them; Section 3 describes the data series and the methodology employed by this study in order to check for evidence of contagion and market interdependence during the recent financial crisis; Section 4 presents and discusses the results of the empirical analysis while Section 5 gives the conclusions of the paper.

\section{Literature Review}

Numerous researchers have previously investigated the presence of contagion and market interdependence in the context of crises' transmission. Dungey et al. (2005) assembled a comprehensive review of the methodologies employed for this purpose and concluded that, despite their diversity, they are still part of a unified framework.

One of the most popular approaches refers to analyzing the correlations between market indices from various countries. Forbes and Rigobon (2002) investigated the crises ranging from the 1987 market crash to the 1997 Asian crisis by means of adjusted correlation coefficients, and found no evidence of contagion and thus concluded that the shocks were transmitted only through market interdependence. Collins and Biekpe (2003) replicated their analysis on the African stock markets and confirmed the occurrence of contagion in the largest ones (Egypt and South Africa). With respect to market interdependence, they identified only regional links and concluded that most African markets are still isolated. Chiang et al. (2007) analyzed the Asian crisis with the aid of a dynamic conditional correlation model. Their results divided the crisis into two phases: first, the contagion phase (when the correlations increased significantly), then, the strengthening of market interdependence (correlations continued to remain high).

In response to the correlation approach, which seemed to favor interdependence, finding limited or no evidence of contagion, factor models for stock returns were employed. On the basis of a two-factor model with time-varying betas, Bekaert et al. (2005) found evidence of contagion during the Asian crisis but not in the case of the Mexican crisis. Corsetti et al. (2005) also investigated the Asian crisis by means of a factor model and confirmed the presence of both contagion and interdependence.

Another major method from previous literature refers to the use of probability models. For example, Fazio (2007) used probit techniques to separate pure contagion from macroeconomic interdependence in the process of crises' propagation. His results indicated a limited occurrence of contagion, especially at regional levels. Also, based on a logit model, Markwat et al. (2009) observed that the probability of a global crash increases in the presence of local and regional ones. 
In his study of the 2007-2009 financial crisis, Samarakoon (2011) modeled the shocks directly and observed that US shocks have a significant impact on the interdependence with foreign markets. However, contagion seemed to be driven mainly by shocks originated from emerging markets. On the other hand, Diebold and Yilmaz (2012) proposed a framework for measuring return and volatility spillovers based on the variance decomposition of VAR models. Their results showed an increase in volatility spillovers, especially from the stock market to other markets, during the recent financial crisis.

\section{Data and Methodology}

In order to investigate the presence of interdependence and contagion during the 20072009 global financial crisis, indices covering all the major markets were required. Among other providers, STOXX Limited offers a wide range of benchmark indices that describe the movement of financial markets. Five such indices, which represent all the important financial centers around the world, were selected for this study, as follows:

- STOXX Africa 90, covering the largest companies in Egypt, Morocco, Nigeria, South Africa and Tunisia;

- STOXX Asia/Pacific 600, covering the largest companies in Australia, Hong Kong, Japan, New Zealand and Singapore;

- $\quad$ STOXX Europe 600, covering companies from 18 developed European countries;

- STOXX Latin America 200, covering the largest companies in Argentina, Brazil, Chile, Columbia, Mexico and Peru;

- STOXX North America 600, covering the largest companies traded on the Canadian and US markets.

Together, the five indices constitute a comprehensive (2090 companies from 36 countries) yet liquid (only the largest and most important companies were selected from each country) representation of the global financial market. For simplicity, from this point on, the indices are referred to only by mentioning their corresponding geographical region.

The data series of the five indices comprise 3318 daily observations covering the interval between 2 January 2002 and 31 December 2014. The period was selected taking into account the availability of the data series, as well as the need to ensure large enough ante and post crisis samples that will allow the investigation of contagion and interdependence. All the series were obtained from www.stoxx.com.

First of all, in order to clearly demarcate the global financial crisis, the monthly log returns of the STOXX Global Total Market Index ${ }^{2}$ were computed for the 2007-2009 interval. The results are plotted in Fig. 1.

2 According to www.stoxx.com, the Global Total Market Index covers 95\% of the free float market capitalization worldwide. 


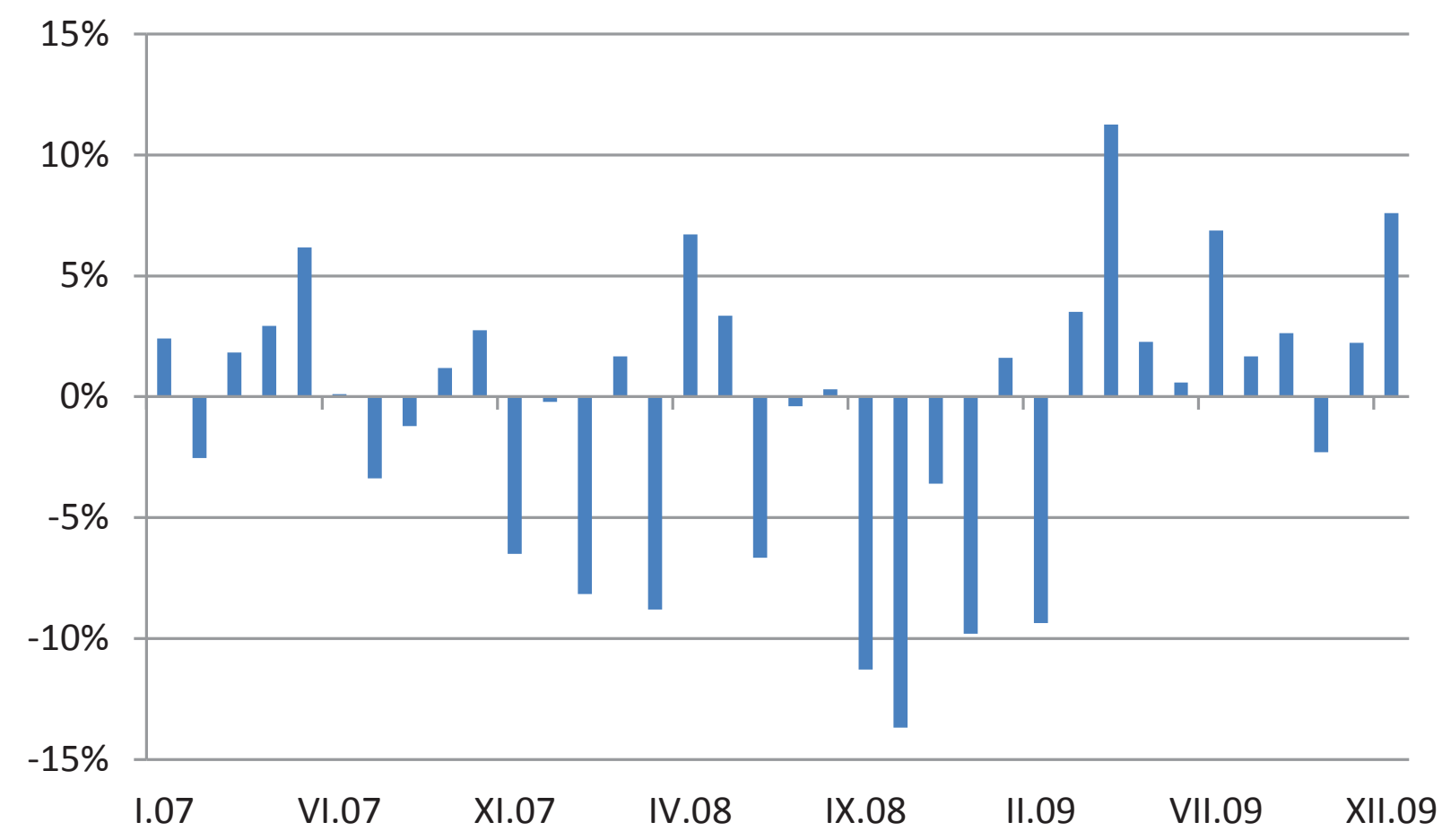

Source: author

As shown above, the global market crisis appears to hit between November 2007 and February 2009 when the Global Total Market Index recorded 11 months of decline out of the total interval of 16 months. During the same period, the five indices retained in this analysis suffered eight months of simultaneous decline losing more than $50 \%$ of their initial values. Consequently, the initial data series were divided into the following intervals: the ante crisis (January 2002 - October 2007, 70 months, 1489 observations), the crisis (November 2007 - February 2009, 16 months, 334 observations) and the post crisis (March 2009 - December 2014, 70 months, 1495 observations). Also, the daily log returns of the five indices were computed for the above mentioned intervals.

Taking into account the methods provided by previous research, the analysis began by computing the unconditional correlations between the returns of the indices for all three intervals in order to investigate their values and their evolution from one interval to another. Both the individual correlations and their value changes across intervals were tested for statistical significance.

Then, following Chiang et al. (2007), the correlation analysis was further expanded by employing dynamic conditional correlations. For this purpose, an exponential smoothing correlation model was calibrated for the data series in accordance with Engle (2002) and Christoffersen (2003). The average values of the conditional correlations and their changes from one interval to another were computed and tested for statistical significance while the results were compared to those obtained for the unconditional correlations.

Finally, in order to cross-check the results provided by the correlation analysis, a different methodology was employed. Thus, the spillover index proposed by Diebold and Yilmaz (2012) allowed for studying potential return spillovers between the five indices. In this view, a second order VAR was estimated between the daily returns of the indices for each interval and the spillover index was computed on the basis of the variance decomposition 
for a 5-step-ahead ${ }^{3}$ forecast. Moreover, since variance decomposition results are sensible to the ordering of the variables, the spillover index was reported for 10 random orderings of the indices.

\section{Results}

Fig. 2 presents the unconditional correlation coefficients between the five indices (in decreasing order by the average correlation for the whole length of the data series) and their evolution across the considered intervals. All the coefficients are statistically significant at $1 \%$ with the exception of the crisis values for the last two pairs: Asia/Pacific - Latin America and Asia/Pacific - North America. As it can be seen, the correlations are quite high for the majority of the indices (except maybe for the correlations between Asia/Pacific and the rest of the world) irrespective of the considered interval. The average value of the unconditional correlation coefficients is 0.335 for the ante crisis period, 0.419 during the crisis and 0.409 after the crisis, amounting to a general average of 0.376 . Therefore, due to the high correlations even outside the crisis period, market interdependence seems to be a plausible factor for the spread of the crisis in the majority of cases.

\section{Figure 2 | The evolution of the unconditional correlation coefficients}

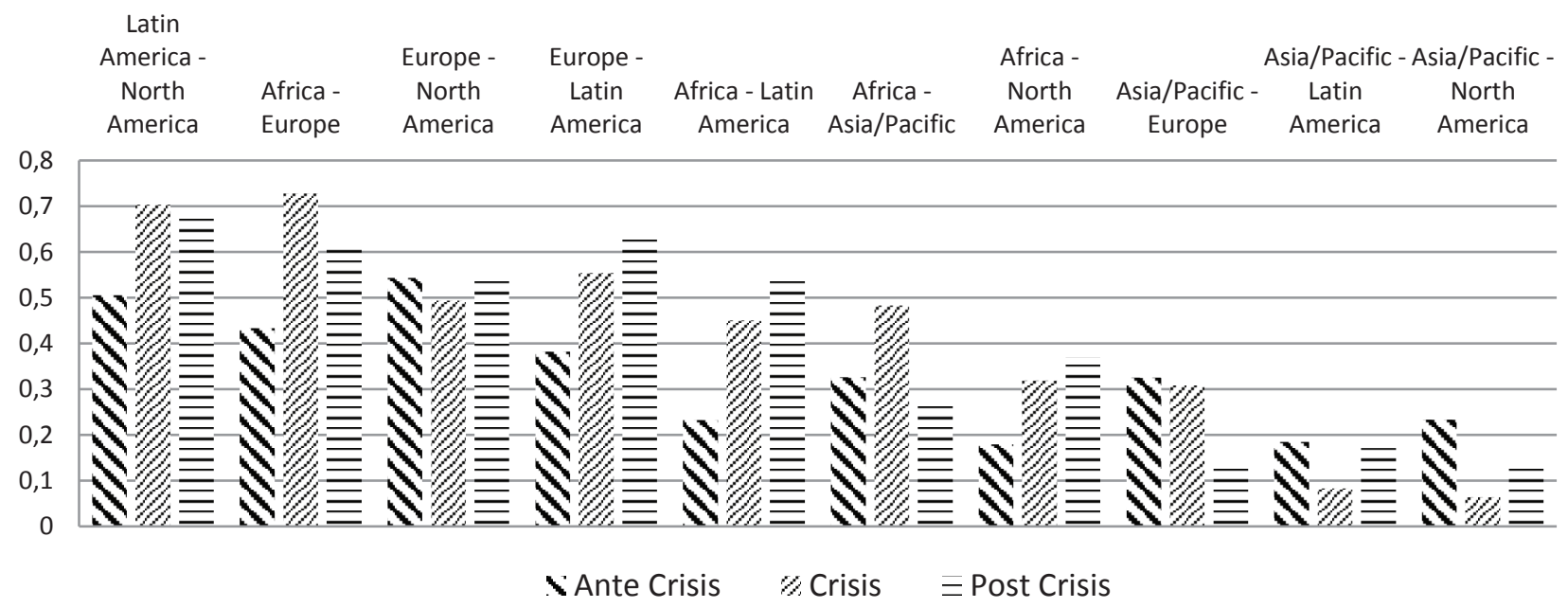

Source: author

The unconditional correlation coefficients also emphasize the strong connections between the financial markets from the Americas, between European markets and the rest of the world (average correlation of 0.463) and bring into attention the integration of African markets (average correlation of 0.395) which are no longer isolated (Collins \& Biekpe 2003). The main exception seems to be the Asia/Pacific region which displays a lower correlation with the other indices (average value of 0.227 ) leaving some room for international portfolio diversification.

Since contagion refers to a significant increase in market comovement, the changes in the values of the unconditional correlations from one interval to another were computed and tested for statistical significance. The results are given in Table 1.

3 The forecast of one week in terms of daily returns. 
Table 1 | The changes in the values of unconditional correlation coefficients with p-values in brackets

\begin{tabular}{|c|c|c|c|c|c|c|c|c|c|c|}
\hline & $\begin{array}{c}\text { Latin } \\
\text { America } \\
- \text { North } \\
\text { America }\end{array}$ & $\begin{array}{c}\text { Africa - } \\
\text { Europe }\end{array}$ & $\begin{array}{c}\text { Europe } \\
- \text { North } \\
\text { America }\end{array}$ & $\begin{array}{c}\text { Europe } \\
- \text { Latin } \\
\text { America }\end{array}$ & $\begin{array}{c}\text { Africa } \\
- \text { Latin } \\
\text { America }\end{array}$ & $\begin{array}{c}\text { Africa } \\
- \text { Asia/ } \\
\text { Pacific }\end{array}$ & $\begin{array}{c}\text { Africa } \\
- \text { North } \\
\text { America }\end{array}$ & $\begin{array}{c}\text { Asia/ } \\
\text { Pacific - } \\
\text { Europe }\end{array}$ & $\begin{array}{c}\text { Asia/ } \\
\text { Pacific } \\
- \text { Latin } \\
\text { America }\end{array}$ & $\begin{array}{c}\text { Asia/ } \\
\text { Pacific } \\
- \text { North } \\
\text { America }\end{array}$ \\
\hline $\begin{array}{c}\text { Crisis } \\
\text { Ante } \\
\text { Crisis }\end{array}$ & 0.198 & 0.295 & -0.05 & 0.172 & 0.218 & 0.157 & 0.14 & -0.017 & -0.102 & -0.17 \\
$(0 \%)$ & $(0 \%)$ & $(36.4 \%)$ & $(0.2 \%)$ & $(0 \%)$ & $(0.4 \%)$ & $(1.1 \%)$ & $(75.5 \%)$ & $(6.2 \%)$ & $(0.2 \%)$ \\
\hline $\begin{array}{c}\text { Post } \\
\text { Crisis - } \\
\text { Crisis }\end{array}$ & -0.027 & -0.115 & 0.054 & 0.073 & 0.098 & -0.209 & 0.051 & -0.175 & 0.089 & 0.066 \\
$(61.8 \%)$ & $(3.5 \%)$ & $(32.1 \%)$ & $(18.4 \%)$ & $(7.3 \%)$ & $(0 \%)$ & $(35.8 \%)$ & $(0.1 \%)$ & $(10.5 \%)$ & $(22.8 \%)$ \\
\hline
\end{tabular}

Source: author

As shown above, in 6 out of 10 cases the unconditional correlation coefficients recorded a significant ${ }^{4}$ increase from the ante crisis to the crisis period. The greatest increase of 0.295 was recorded between Africa and Europe, while the lowest increase of 0.14 (but still statistically significant) was recorded between Africa and North America. Therefore, the results show evidence of contagion in more than half of the cases especially towards African markets (all 4 correlation coefficients recorded a significant increase) and Latin American markets ( 3 out of 4 correlation coefficients recorded a significant increase). Looking at the remaining cases, some interesting things can be noticed. Firstly, most correlations between Asia/Pacific and the rest of the world do not change significantly due to the crisis and in one case they even decrease by 0.17 , a result which is statistically significant. This confirms the previous conclusion that markets from the Asia/Pacific region allowed for international diversification even during the recent crisis. Secondly, the correlations between Europe and North America, while already being at a high level, do not change significantly during all the considered intervals. Therefore, these markets appear to be highly interdependent but with no obvious signs of contagion.

On the other hand, the lower half of Table 1 brings into attention a concerning fact: only in 3 out of 10 cases the correlation coefficients recorded a significant decrease after the crisis. In all the other cases, the changes of the correlation coefficients are not significant meaning that, most likely, the crisis accentuated the interdependence of financial markets. These results are in line with the findings of Chiang et al. (2007) who also divided the Asian crisis into a contagion phase, followed by an interdependence phase with continuous high correlations.

The correlation analysis was further expanded by taking into account dynamic conditional correlations obtained via an exponential smoothing model. The model could not be calibrated for the Africa - Asia/Pacific and Europe - North America pairs leaving the other eight cases for analysis. To begin with, conditional correlations do not provide new insights regarding the most interconnected markets and the general level of interdependence. The ordering according to the average correlation level stays the same except for the last two (Asia/Pacific - Latin America and Asia/Pacific - North America) which switch places. Also, the presence of market interdependence cannot be ignored, the average values of the conditional correlations being 0.326 before the crisis, 0.37 during the crisis and reaching to 0.397 after the crisis.

4 Considering a significance level of $5 \%, 5$ cases if a $1 \%$ significance level is considered 
Table 2 | The changes in the values of average conditional correlations with p-values in brackets

\begin{tabular}{|c|c|c|c|c|c|c|c|c|}
\hline & $\begin{array}{c}\text { Latin } \\
\text { America } \\
- \text { North } \\
\text { America }\end{array}$ & $\begin{array}{c}\text { Africa - } \\
\text { Europe }\end{array}$ & $\begin{array}{c}\text { Europe } \\
- \text { Latin } \\
\text { America }\end{array}$ & $\begin{array}{c}\text { Africa } \\
- \text { Latin } \\
\text { America }\end{array}$ & $\begin{array}{c}\text { Africa } \\
- \text { North } \\
\text { America }\end{array}$ & $\begin{array}{c}\text { Asia/ } \\
\text { Pacific - } \\
\text { Europe }\end{array}$ & $\begin{array}{c}\text { Asia/ } \\
\text { Pacific } \\
- \text { Latin } \\
\text { America }\end{array}$ & $\begin{array}{c}\text { Asia/ } \\
\text { Pacific } \\
- \text { North } \\
\text { America }\end{array}$ \\
\hline $\begin{array}{c}\text { Crisis } \\
- \text { Ante } \\
\text { Crisis }\end{array}$ & $\begin{array}{c}0.142 \\
(6.46 \%)\end{array}$ & $\begin{array}{c}0.29 \\
(0 \%)\end{array}$ & $\begin{array}{c}0.127 \\
(1.64 \%)\end{array}$ & $\begin{array}{c}0.148 \\
(0 \%)\end{array}$ & $\begin{array}{c}0.069 \\
(0.7 \%)\end{array}$ & $\begin{array}{c}-0.1 \\
(2.4 \%)\end{array}$ & $\begin{array}{c}-0.148 \\
(0 \%)\end{array}$ & -0.181 \\
\hline $\begin{array}{c}\text { Post } \\
\text { Crisis - } \\
\text { Crisis }\end{array}$ & -0.012 & -0.119 & 0.06 & $\begin{array}{c}0.144 \\
(0 \%)\end{array}$ & $\begin{array}{c}0.089 \\
(0 \%)\end{array}$ & $\begin{array}{c}-0.133 \\
(0.3 \%)\end{array}$ & $\begin{array}{c}0.117 \\
(0 \%)\end{array}$ & 0.073 \\
$(0.8 \%)$
\end{tabular}

Source: author

The changes in the average values of the conditional correlations (reported in Table 2) confirm the presence of contagion in four out of eight cases, namely Africa - Europe, Europe - Latin America, Africa - Latin America and Africa - North America. All these cases also recorded significant increases of the unconditional correlation coefficients during the crisis period. Therefore, both unconditional and conditional correlations indicate the presence of contagion between certain markets during the recent crisis. The markets most affected by contagion seem to be Africa and Latin America while the major financial centers from North America and Europe appear to be closely interconnected with no significant changes. Again, the Asia/Pacific index displays an uncommon behavior with significant decreasing correlations against all the other indices, confirming the previous conclusion that diversification on these financial markets could have mitigated the losses during the crisis.

The evolution of the conditional correlations after the crisis emphasizes the same concerning fact: only in two out of eight cases do the correlations decrease significantly, while in four of the other cases the correlations experience a significant increase during the post crisis interval. These results give good cause to believe that the global financial crisis strengthened the interdependence between financial markets making them more vulnerable to the transmission of future shocks.

Finally, in order to validate the results of the correlation analysis, the spillover index between the returns of the five indices was computed for each interval according to the methodology developed by Diebold and Yilmaz (2012). The robustness of the spillover index was checked by using 10 random orderings of the market indices and the results are reported in Table 3.

Table 3 | The spillover index

\begin{tabular}{|l|c|c|c|c|c|c|c|c|c|c|c|}
\hline \multirow{2}{*}{$\begin{array}{l}\text { Spillover } \\
\text { Index }\end{array}$} & \multicolumn{7}{|c|}{ Random Orderings } & $\begin{array}{c}\text { Average } \\
\text { Index }\end{array}$ \\
\cline { 2 - 12 } \\
\hline $\begin{array}{l}\text { Ante } \\
\text { Crisis }\end{array}$ & $24.9 \%$ & $25.4 \%$ & $23.7 \%$ & $24.9 \%$ & $23.8 \%$ & $24.4 \%$ & $23.1 \%$ & $23.8 \%$ & $24.5 \%$ & $24.2 \%$ & $24.3 \%$ \\
\hline Crisis & $47.3 \%$ & $47.4 \%$ & $45.2 \%$ & $47.1 \%$ & $44.7 \%$ & $45.7 \%$ & $45.2 \%$ & $46.3 \%$ & $47.1 \%$ & $45.7 \%$ & $46.2 \%$ \\
\hline $\begin{array}{l}\text { Post } \\
\text { Crisis }\end{array}$ & $35.8 \%$ & $35.5 \%$ & $35.3 \%$ & $36.2 \%$ & $35.2 \%$ & $35.2 \%$ & $34.6 \%$ & $36.0 \%$ & $36.0 \%$ & $34.9 \%$ & $35.5 \%$ \\
\hline
\end{tabular}

Source: author 
As shown above, the values of the spillover index are quite homogenous and the random orderings do not have a significant impact on the results. Moreover, the average values for each interval confirm at least two conclusions of the correlation analysis. Firstly, there appears to be a significant increase of the spillover between returns during the crisis interval which supports the existence of contagion episodes as evidenced by the correlation analysis. Secondly, while the average spillover index decreases after the crisis, it still remains higher than its initial value, confirming the intensification of global market interdependence.

\section{Conclusion}

This paper investigated the presence of contagion and interdependence during the 20072009 financial crisis with the aid of five aggregate indices covering 2090 companies traded on 36 markets from six continents. The empirical study focused on analyzing the evolution of both unconditional and conditional correlations and was further developed by taking into account the existence of spillover effects. The results of the study emphasize three major conclusions:

- The global financial markets exhibited a high degree of integration even before the occurrence of the crisis. This is most visible in the case of Europe and North America which seem to be strongly interconnected irrespective of time interval;

- There appears to be evidence of contagion during the crisis for about half of the considered cases, especially from the developed financial markets of Europe and North America to the emerging centers in Africa and Latin America. However, the markets from the Asia/Pacific region displayed a distinct behavior characterized by lower correlations, that further decreased during the crisis, which may have given opportunities for international portfolio diversification and mitigation of losses;

- After the contagion episodes some of the correlation coefficients decreased but did not return to their initial levels. As a consequence, the crisis seems to have intensified the interdependence between financial markets.

While the conclusions of this study allow for a better understanding of crises' propagation, they also have several implications for investors and fund managers seeking to benefit from international portfolio diversification. To begin with, the high degree of interdependence between mature markets and between markets from neighboring regions diminishes the opportunities for international diversification which might make the emerging financial centers more appealing to investors. Yet, during the crisis, emerging markets were subject to important contagion episodes from their mature counterparts so the diversification effects were drastically limited. Nonetheless, the empirical analysis indicated that there is still good news for investors: the markets from the Asia/Pacific region displayed lower correlations with the rest of the world, most of them further decreasing during the crisis. Consequently, these markets appeared to offer a safe haven in times of intense financial distress. However, considering the continuous process of financial integration, which seems to have been further strengthened by the global crisis, effective portfolio diversification may prove an increasingly difficult task in the future. 


\title{
References
}

Bekaert, G., Harvey, C. R., \& Ng, A. (2005). Market integration and contagion, Journal of Business, 78(1), 39-69.

Chiang, T. C., Jeon, B. N. \& Li, H. (2007). Dynamic correlation analysis of financial contagion: Evidence from Asian markets. Journal of International Money and Finance, 26(7), 1206-1228.

Christoffersen, P. F. (2003). Elements of Financial Risk Management. San Diego: Academic Press.

Collins, D., \& Biekpe, N. (2003). Contagion and interdependence in African stock markets. South African Journal of Economics, 71(1), 181-194.

Corsetti, G., Pericoli, M., \& Sbracia, M. (2005). Some contagion, some interdependence: More pitfalls in tests of financial contagion. Journal of International Money and Finance, 24(8), 1177-1199.

Diebold, F. X., \& Yilmaz, K. (2012). Better to give than to receive: Predictive directional measurement of volatility spillovers. International Journal of Forecasting, 28(1), 57-66.

Dungey, M., Fry, R., Gonzalez-Hermosillo, B., \& Martin, V. L. (2005). Empirical modelling of contagion: a review of methodologies. Quantitative Finance, 5(1), 9-24.

Engle, R. F. (2002). Dynamic Conditional Correlation: A Simple Class of Multivariate Generalized Autoregressive Conditional Heteroskedasticity Models. Journal of Business \& Economic Statistics, 20(3), 339-350.

Fazio, G. (2007). Extreme interdependence and extreme contagion between emerging markets. Journal of International Money and Finance, 26(8), 1261-1291.

Forbes, K. J., \& Rigobon, R. (2002). No contagion, only interdependence: Measuring stock market comovements. The Journal of Finance, 57(5), 2223-2261.

Markwat, T., Kole, E., \& Van Dijk, D. (2009). Contagion as a domino effect in global stock markets. Journal of Banking \& Finance, 33(11), 1996-2012.

Samarakoon, L. P. (2011). Stock market interdependence, contagion, and the US financial crisis: The case of emerging and frontier markets. Journal of International Financial Markets, Institutions \& Money, 21(5), 724-742.

\author{
Author \\ Filip lorgulescu \\ Assistant Professor \\ The Bucharest University of Economic Studies, Romania \\ Piața Romană no. 6, Bucharest, Romania \\ filip.iorgulescu@fin.ase.ro
}

This paper was co-financed from the European Social Fund, through the Sectorial Operational Programme Human Resources Development 2007-2013, project number POSDRU/159/1.5/S/138907 "Excellence in scientific interdisciplinary research, doctoral and postdoctoral, in the economic, social and medical fields - EXCELIS", coordinator: The Bucharest University of Economic Studies. 